\title{
Biodegradation of Phenolic Hydrocarbon Waste Using Bacterial Consortium from Cattle Rumen
}

\author{
Ibnu Maulana, Heri Hermansyah, Arina Shallyta, and Hanif Yuliani
}

\begin{abstract}
Waste water in Indonesia especially from industries contains phenol around $16 \mathrm{ppm}$ which is higher than regulated standard quality of phenol in waste water $(2 \mathrm{ppm})$. Phenol is a toxic aromatic hydrocarbon which is dangerous and difficult to degrade. Therefore, we conduct a study about biodegradation process of hydrocarbon (phenol) liquid waste using bacterial consortium from cattle rumen. In this paper, the researchers discussed how to produce, effect of incubation medium, and identification of bacterial consortium which is isolated from the cattle rumen and petroleum sludge, both solid and liquid form. Based on gram-staining analysis, cattle rumen bacteria are gram-positive and gram-negative bacteria. Phenol biodegradation using cattle rumen bacterial consortium, the obtained $k$ value sure $0.174 ; 1.125 ; 1,527 ; 0.007$ and 0.116 , which are based on the concentration of phenol of 12, 24, 48, 72 and 120. Similarly, for petroleum sludge, the obtained $k$ values respectively are $0.212 ; 1.029 ; 1.26 ; 1.74$ and 2.196 .
\end{abstract}

Index Terms-Bacterial consortium, cattle rumen, phenol biodegradation.

\section{INTRODUCTION}

Indonesia, is one of petroleum producer country, has problem in treating distillation process waste water. Petroleum industry has an important role in Indonesia because of abundant petroleum resources make Indonesia become an attractive investment destination in the petroleum sector. However, processing of waste coming from the petroleum industry has not been much so that waste from the petroleum industry to pollute the waters especially phenol exceeds a specified limit. Lack of waste treatment leads to accumulation of waste petroleum industry in particular phenol were quite high in the polluted waters [1]. The phenol content in wastewater is around $10-50 \mathrm{ppm}$ [2]. This concentration is much higher than the maximum allowable limit (2 ppm) as specified based on Regulation of the Environment Ministry by the standard quality of waste water exploration and production activities of oil and gas from onshore facilities type of waste produced water

Phenol is a toxic aromatic hydrocarbon which can reduce enzymatic activity, dangerous for health, cause death of animals in the water (phenol content ranging from 5-15 mg/l can kill fish) and increase the growth of harmful aquatic plants [3]. In another research, once wastewater containing phenolic compounds is discharged into a receiving body of water, it endangers for fish live even at a relatively low

Manuscript received June 6, 2016; revised October 21, 2016. This work was supported in part by the DRPM Ministry of Research and Higher Education Republic of Indonesia and DRPM Universitas Indonesia.

The authors are with the Department of chemical engineering, Faculty of Engineering, Universitas Indonesia, Depok 16424, Indonesia (e-mail: heri@che.ui.ac.id). concentration (5-25 mg/l) [4]. Existing phenol degradation is often inefficient, due to self-inhibition on high concentration, accumulation of intermediates in the metabolism of phenol, and the release of soluble microbial products [5], [6]. There are some methods to treat the phenolic hydrocarbon waste and one of treatment method is biodegradation. Biodegradation is treatment method using microorganism to decrease organic and toxic substance. Principally, microbial biodegradation release into the environment is contaminated, increasing the ability of indigenous microbes and the use of microbes in special reactors [7]. Many microorganisms that can be used as bioremediation agents are bacteria, fungi, and algae with certain species as bioremediation agents. However, single microorganisms are not able to lose all of the compounds from the waste mixture so that the required form of bacterial consortium that not only has a broad substrate specificity, but also the degradation in achieved in cooxidation and commensalisme systems. In recent years, study about capability of bacterial consortium as microorganism from petroleum sludge and lubricant for phenolic hydrocarbon waste biodegradation are conducted [8], [9] and studies on the ability of the bacterial consortium to degrade hydrocarbons from waste and petroleum products. like petroleum sludge, lubricating oil, and turbine oil. However, no studies related to the use of cattle rumen bacterial consortium as phenol waste bioremediation agent. Bacterial consortium live in anaerobic conditions make bioremediation process is advantageous economically because aeration process is not required to meet the needs of oxygen in the process of biodegradation. In addition, bacterial consortium can be compared with the bacterial consortium isolation results that have been there for the degradation of petroleum sludge so that the results can be seen whether the bacteria consortium derived from cattle rumen can compete with the bacterial consortium which has no isolation results for the degradation of petroleum sludge to reduce phenol in laboratory scale. Now, in this research, we conduct a study about biodegradation of phenolic hydrocarbon waste using bacterial consortium from cattle rumen because bacterial in cattle rumen usually work at anaerob condition and appropriate to be implemented for anaerobic biodegradation for phenolic hydrocarbon waste. Objectives of this research are to produce bacterial consortium by isolating and culturing microbial consortium from cattle rumen. Then, characteristics bacterial consortium from cattle rumen will be compared with bacterial consortium from petroleum sludge and will be used for phenol biodegradation.

\section{MATERIALS AND METHODS}




\section{A. Materials}

The materials used in this study are cattle rumen, petroleum sludge, $\mathrm{Na}_{2} \mathrm{HPO}_{4}, \mathrm{KH}_{2} \mathrm{PO}_{4}, \mathrm{NH}_{4} \mathrm{Cl}, \mathrm{NaCl}$, phenol, nutrient broth, nutrient gelatin, yeast extract, blood, violet crystal, iodine solution, 95\% alcohol, acetone (3:1), concentrated $\mathrm{NH}_{4} \mathrm{OH}$, distilled water, 4 amino antipirin solution, $\mathrm{K}_{3} \mathrm{Fe}(\mathrm{CN})_{6}$ solution, and carrageenan.

\section{B. Methods}

\section{1) Bacteria isolation}

Bacteria from petroleum sludge and cattle rumen mucus which fermented for 3 days has been innoculated in 3 kinds of medium: yeast extract, nutrient agar, and blood. Then, the bacteria of each innoculation were isolated in agar medium which added with synthetic phenol to obtained pure culture of bacterial consortium.

\section{2) Bacteria identification}

Identification of bacteria are colony form, gram staining, and bacterial growth. The colony form and gram staining identification refer to Bergey's Manual of Determinative Bacteriology [10]. Bacterial growth was determined by optical density of medium using UV-VIS spectrofotometer $600 \mathrm{~nm}$.

\section{3) Phenol biodegradation}

Bacteria from cattle rumen were dissolved in $100 \mathrm{ml} \mathrm{NPK}$ medium $\left(6 \%\right.$ wt $\mathrm{Na}_{2} \mathrm{HPO}_{4}, 3 \%$ wt $\mathrm{KH}_{2} \mathrm{PO}_{4}, 1 \%$ wt $\mathrm{NH}_{4} \mathrm{Cl}$, $0.5 \%$ wt $\mathrm{NaCl}$ dissolved in distilled water). Then, various concentration of phenol was added to medium and shaken at $25-30^{\circ} \mathrm{C}$ (room temperature), $90 \mathrm{rpm}$, for $16 \mathrm{~h}$. Sampling for activity test every $2 \mathrm{~h}$ during $16 \mathrm{~h}$.

\section{4) Activity test}

The activity of bacteria for phenol biodegradation was determined by calculate difference of phenol concentration in initial medium and sample medium. The phenol concentration in medium was determined according 4-aminoantipirin method using UV-VIS spectrofotometer
$510 \mathrm{~nm}$ (SNI 06-6989.21-2004). $5 \mathrm{ml}$ sample was incubated with $\mathrm{NH}_{4} \mathrm{OH}$, buffer phospate, 4 aminoantipirin $2 \%$ solution, and $\mathrm{K}_{3} \mathrm{Fe}(\mathrm{CN})_{6} 8 \%$ before measured by spectrofotometer.

\section{5) Bacterial immobilization}

$6 \mathrm{~g}$ carrageenan was dissolved in $200 \mathrm{ml}$ distilled water and sterilized by autoclave. Then, $2 \mathrm{ml}$ of bacteria-nutrient both solution was added to $100 \mathrm{ml}$ carrageenan solution and shaking for 5 minutes. $\mathrm{KCl} 3 \mathrm{M}$ was slowly dropped to the solution and incubated for $24 \mathrm{~h}$, then separated by filtration.

\section{RESUlT AND DisCUSSIONS}

\section{A. Cattle Rumen Bacteria Identification}

After the test morphology and physiology, isolates isolated bacteria species were identified through the identification table of Bergey's manual [10], it is obtained that in cattle rumen, the bacteria are gram-positive, regular rod-shaped, irregular rod-shaped and irregular spherical-shaped, while the gram negative bacteria have regular rod-shaped and spherical-shaped. These results are similar to the results obtained from the bacteria isolated from petroleum sludge.

The results of the bacterial isolation from a variety of media, that is from on isolate from cattle rumen and petroleum sludge could be gram-positive or gram-negative, and have rod, irregular rod, and spherical shaped as shown at table 1 below. The results of the bacterial isolation from petroleum sludge are almost the same as the results of the isolation from cattle rumen, yet for blood medium, there are a lot of bacteria that are suspected to belong to the genus of Bacillus sp. as much as $55 \%$ and as much as $45 \%$ of the bacteria are gram-negative spherical-shaped bacteria. Bacillus sp. have ability to live in many medium at extreme condition. Furthermore, yeast extract medium contain more nutrition that bacterial needed than nutrient broth and blood medium.

TABLE I : BACTERIAL IDENTIFICATION RESULTS

\begin{tabular}{|c|c|c|c|c|c|c|}
\hline & \multicolumn{3}{|c|}{ Cattle Rumen } & \multicolumn{3}{|c|}{ Petroleum Sludge } \\
\hline & Yeast Extract & Nutrient Broth & Blood & Yeast Extract & Nutrient Broth & Blood \\
\hline Gram-Positive, Rod-Shaped & $20 \%$ & $25 \%$ & $45 \%$ & $20 \%$ & $25 \%$ & $55 \%$ \\
\hline $\begin{array}{l}\text { Gram-Positive, Irregular } \\
\text { Rod-Shaped }\end{array}$ & $20 \%$ & $20 \%$ & $20 \%$ & $20 \%$ & $20 \%$ & - \\
\hline Gram-Negative, Rod-Shaped & $20 \%$ & $15 \%$ & - & $20 \%$ & $15 \%$ & - \\
\hline Gram-Positive, Spherical-Shaped & $20 \%$ & $15 \%$ & - & $20 \%$ & $15 \%$ & - \\
\hline Gram-Negative, Spherical Shaped & $20 \%$ & $25 \%$ & $35 \%$ & $20 \%$ & $25 \%$ & $45 \%$ \\
\hline
\end{tabular}

\section{B. Bacteria Consortium Growth}

To obtain ideal biodegradation, bacterial growth factors must be optimal, such as substrate concentration, $\mathrm{pH}$, and level of nutrition. In Fig. 1 and 2 below, shown bacteria consortium growth from cattle rumen and petroleum sludge for various phenol concentration. In Fig 1, the bacteria growth is increase along of time, it means that bacteria is grown. Furthermore, the decreasing line in Fig. 1 means that bacteria are in a retardation phase. As known before, there is sixth phase of bacteria growth. First, lag phase when bacteria is adapt with its environment. Second, acceleration phase when bacteria is grown fast. Third, exponential phase when bacteria growth rate is constant. Fourth, retardation phase when bacteria growth rate is decreasing. Fifth, stationer phase when there is no bacteria growth rate. Last, death phase when bacteria growth rate is negative. In Fig. 2, growth of bacteria from petroleum sludge for phenol concentration 72 and $120 \mathrm{ppm}$ still in acceleration phase.

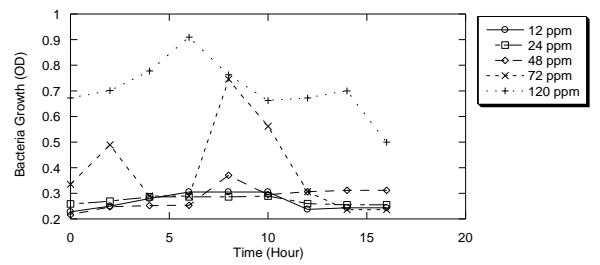

Fig. 1. Growth of bacteria consortium from cattle rumen for various phenol concentration. 


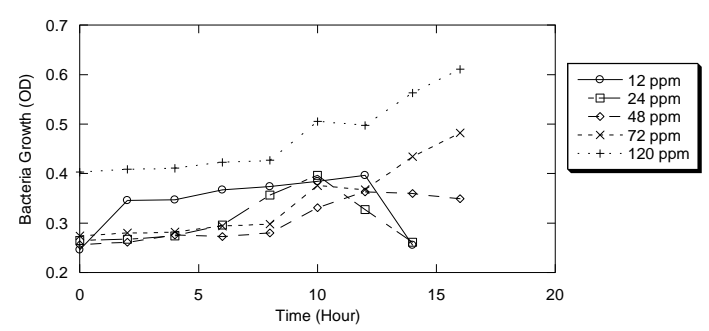

Fig. 2. Growth of bacteria consortium from petroleum sludge for various phenol concentration.

\section{Biodegradation Phenol Using Cattle Rumen Bacteria}

The results of bacteria isolation, from both the cattle rumen and petroleum sludge, are able to degrade phenol up to 120 ppm. The activity of bacterial consortium from cattle rumen and petroleum sludge to phenol degradation with various concentration are shown in Fig. 3. From concentration data every $2 \mathrm{~h}$ during $16 \mathrm{~h}$, we can calculate degradation rate $(\mathrm{k})$ with equation in table 2 . Phenol biodegradation using cattle rumen bacterial consortium, the obtained $\mathrm{k}$ value sure 0.174 ; $1.125 ; 1,527 ; 0.007$ and 0.116 , which are based on the concentration of phenol of 12, 24, 48, 72 and 120. Similarly, for petroleum sludge at the same concentrations, the obtained $\mathrm{k}$ values respectively are $0.212 ; 1.029 ; 1.26 ; 1.74$ and 2.196 .

\begin{tabular}{|c|c|}
\hline Substrate & Equation \\
\hline \multirow[t]{7}{*}{ PAHs } & Order 0 \\
\hline & {$[C]_{t}=-k t+[C]_{o}$} \\
\hline & Order 1 \\
\hline & $\ln [C]_{t}=-k t+\ln [C]_{0}$ \\
\hline & Order 2 \\
\hline & $\frac{1}{1}=-k t+\frac{1}{1}$ \\
\hline & $\overline{[C]_{t}}=-k \tau+\overline{[C]_{0}}$ \\
\hline
\end{tabular}

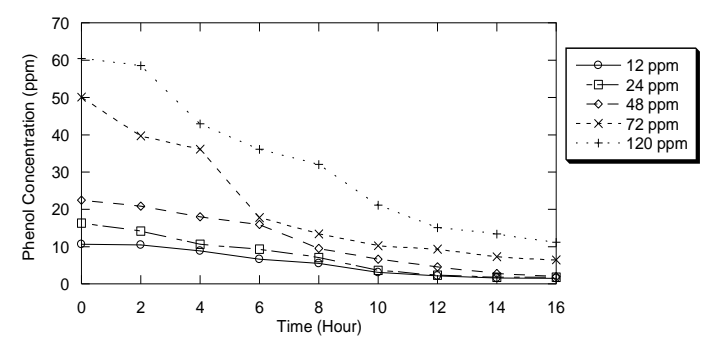

(a)

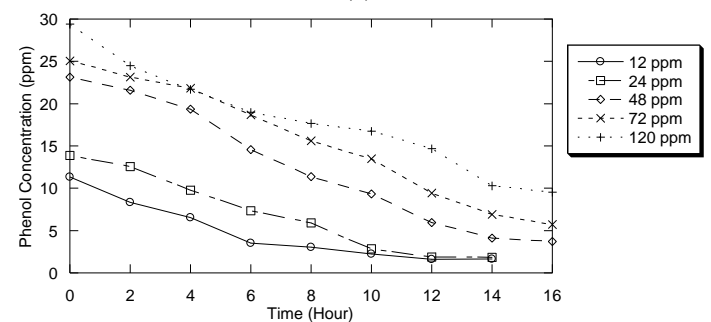

(b)

Fig. 3. Results of biodegradation test using bacterial consortium from cattle rumen (a) and petroleum sludge (b).

\section{Biodegradation Phenol Using Cattle Rumen Bacteria}

The result of bacterial consortia production in liquid medium is 1.5 liter within one batch; while the immobilization result in one batch is 50 grams. We produce bacteria which have move to liquid medium of about 1.5 liters in one batch in accordance with the procedure. Cell immobilization is done to obtain longer life and keep its catalytic ability.

\section{CONCLUSION}

The identification of bacteria from cattle rumen is similar with bacteria from petroleum sludge in yeast extract and nutrient broth medium. It contain gram-positive rod-shaped, gram-positive irregular rod-shaped, gram-negative rod-shaped, gram-positive spherical-shaped, and gram-negative spherical shaped of bacteria. In medium and nutrient broth yeast extract. Bacterial consortium in the cattle rumen and bacterial consortium on petroleum sludge have same bacterial composition. They are gram-positive rod-shaped, gram-positive irregular rod-shaped, gram-negative rod-shaped, gram-positive spherical-shaped, and gram-negative spherical-shaped by $20 \%$ for yeast extract. Gram-positive rod shape and gram-negative spherical-shaped by $25 \%$, gram-positive irregular rod-shaped by $20 \%$, gram-negative rod-shaped and gram-positive spherical-shaped by $15 \%$ for nutrient broth. While for the blood medium, both in cattle rumen and petroleum sludge.have a varied bacterial composition. Bacterial consortium type of gram-positive rod-shaped and gram-negative spherical-shape in cattle rumen have lower bacterial composition than petroleum sludge. Gram-positive rod-shape in the cattle rumen by $45 \%$ and $55 \%$ in petroleum sludge. Gram-negative spherical-shaped in the cattle rumen by $35 \%$ and $55 \%$ in petroleum sludge. But, gram-positive irregular rod-shaped identified in cattle rumen only in blood medium with 20\%. Gram-negative rod-shaped and gram-positive spherical-shaped not identified in the two types of bacterial consortium eiither in cattle rumen and petroleum sludge with blood medium.

From the experiment, bacteria in cattle rumen and petroleum sludge both can live in maximum $120 \mathrm{ppm}$ of phenol concentration. The kinetics result of synthesis of phenol biodegradation is shown with $\mathrm{k}$ value for cattle rumen bacterial consortium and petroleum sludge for phenol concentration of $12,24,48,72$, and $120 \mathrm{ppm}$. The $\mathrm{k}$ value for phenol biodegradation using cattle rumen bacterial are 0.174 ; $1.125 ; 1,527 ; 0.007$ and 0.116 , while $\mathrm{k}$ value for phenol biodegradation using petroleum sludge are $0.212 ; 1.029 ; 1.26$; 1.74 and 2.196. From this result, cattle rumen bacterial as good as petroleum sludge to decomposed phenol. Besides that, the cell immobilization result in 50 grams of immobilized cell to improve its catalytic ability. This bacterial consortium is potential to scale up and applied at wastewater treatment in production of petroleum gas, because it can decomposed phenol 48 ppm to less than 2 ppm in 16 hours.

\section{REFERENCES}

[1] I. S. Zvyagintseva et al., "Degradation of machine oil by nocardioform bacteria," Microbiology, vol. 70, pp. 270-276, 2001.

[2] D. Murtyaningsih, Biodegradasi Fenol, Indonesia : Jakarta, 2013.

[3] F. Kafilzadeh et al., "Isolation and identification of fenol degrading bacteria from lake parishan and their growth kinetic assay," African Journal of Biotechnology, pp. 6721-6726, 2010.

[4] J. Yan et al., "Phenol biodegradation by the yeast Candida tropicalis in the presence of m-cresol," Biochem Eng J., vol. 29, pp. 227-23, 2006.

[5] E. Namkung and B. E. Rittmann, "Soluble microbial products (SMP) formation kinetics by biofilms," Water Res., vol. 20, no. 6, pp. 795-806, 1986.

[6] G. Huang et al., "Effect of hydraulic retention time on the formation of soluble microbial products in aerobic completely stirred tank reactor," Journal of East China University of Science and Technology (Natural Science Edition), vol. 35, no. 1, pp. 66-70, 2009. 
[7] D. Suryanto, Biodegradasi Aerobik Senyawa Hidrokarbon Aromatik Monosiklis Oleh Bakteri, Medan: Universitas Sumatera Utara, 2003.

[8] K. S. M. Rahman et al., "Enhanced bioremediation of n-alkane in petroleum sludge using bacterial consortium amended with rhamnolipid and micronutrients," Bioresour Technol., vol. 90, pp. 159-168, 2003.

[9] N. Vasudevan and P. Rajaram, "Bioremediation of oil sludge contaminated soil," Environ Int., vol. 26, pp. 409-411, 2001.

[10] H. G. John, Bergey's Manual of Determinative Bacteriology, USA: Baltimotr, Maryland, 1994.

[11] A. Wijanarko et al., "Isolation and properties characterization of biosurfactant synthesized by pyrene degrading Bacillus subtilis C19," $J$. Chem. Chem. Eng., vol. 6, 2012, pp. 889-896.

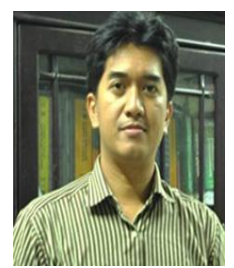

Heri Hermansyah was born in Sukabumi, on January 18, 1976. He completed S1 Gas and Petrochemical Engineering University Indonesia (1998). In 2003, he earned his masters of engineering in the Department of Chemical Engineering at the Tohoku University, Japan, and in 2006 earned a doctor of philosophy in engineering in the same place. All his thesis of bachelor degree, master's, and doctoral all deals in the field of reaction kinetics. since 2008 until 2013 has been chairman of bioprocess technology study program or the head of a Research Group of Industrial Bioprocess Technology, Department of Chemical Engineering,
Universitas Indonesia. He is professor since 2013. His numerous awards related to academic achievement as a university lecturer in Indonesia has been achieved, among others: Runner Up of the Best Young Researchers UI (2008), the Best Researchers UI (2009) in the field of Science and Technology, the Best Researchers in Faculty of Engineering, Universitas Indonesia $(2008,2009)$, and Outstanding Lecturers of Universitas Indonesia (2010).

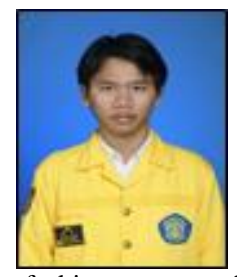

Ibnu Maulana was born in Jakarta, on June 25, 1994. He completed the bachelor program in the field of bioprocess technology (2016) in Universitas Indonesia. During college, he was actived in academic activities both on campus and outside campus. He had joined as a member in the Society of Biological Engineering Universitas Indonesia Student Chapter. He was actived as lecturer assistant in the introduction of bioprocess technology, biochemical engineering, and bioreactor engineering subject and was an laboratory assistant of unit operations of bioprocess 1 . His achievements that have been inscribed among others finalists academic paper writing field of food, agriculture, and fisheries CISAK (2015), Best Poster Presentation in AFOB $6^{\text {th }}$ Regional Symposium (2015), the top 30 Chemical Product Design Competition 2015 Petrogas Days UI International Level (2015). 